\title{
POLYPHONY AND THE CARNIVALESQUE: INTRODUCING THE TERMS
}

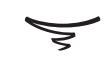

The First Hundred Years of Mikhail Bakhtin (Princeton University Press, 1997) was my attempt to contextualize, for an American audience, some of the more accessible aspects of the Russian recuperation of Bakhtin. The following two excerpts, taken from chapters 3 and 4, summarize two of the most controversial ideas in the Bakhtin canon: the polyphonic novel and carnival. Each may be considered an extreme - and thus instructive - case of dialogism: one of the word, the other of the body.

When this centennial book was conceived in the mid-1990s, the backlash against the "cult of Bakhtin" was at its height. Since that time, the meticulous research of a handful of scholars, the editors of Bakhtin's Collected Works in Moscow and also, outside of Russia, Craig Brandist, Ken Hirschkop, Vadim Liapunov, Brian Poole and Galin Tihanov, documented Bakhtin's uncredited sources and intellectual inspirations, providing them with appropriate context. As the impatient "decrowning" phase was replaced by a more sober assessment, Bakhtin gradually moved into the category of world classic, the position he now holds in the second decade of the $21^{\text {st }}$ century.

Opening segment from chapter 3 of The First Hundred Years of Mikhail Bakhtin:

POLYPHONY, DIALOGISM, DOSTOEVSKY (1997)

Let us recall the basic theses of Bakhtin's book on Dostoevsky. It begins with a familiar Formalist complaint: that literary scholars, dazzled by Dostoevsky's contributions to theology, moral philosophy, psychology and Russian nationalism, have failed to appreciate his even greater contribution to literary art. This oversight Bakhtin intends to correct - with, however, a concept of "literariness" that most Formalist critics would have found highly suspect. Whereas the Russian Formalists preferred to examine hard-edged mechanical or impersonal devices such as defamiliarization, 
retardation, parody, the "stringing" of events and step-wise construction in an author's literary texts, Bakhtin focuses almost entirely on a single (and decisively soft) "device": human consciousness.

In order to examine degrees of consciousness in the aesthetic realm, Dostoevsky created (or perhaps discovered) polyphony. According to Bakhtin, this idea was so radical that it caused a genuine paradigm shift, a "Copernican revolution," in the history of the novel. In the more "Ptolemaic" worldview that preceded it, an author sits at the center of things like Jehovah, passing out bits of consciousness piecemeal to the characters taking shape under the authorial pen, just enough to each person so that the cast of characters could obediently act out its predetermined roles. But Dostoevsky, Bakhtin intimates, endorsed a more "New Testament" model of authorship, one based on unresolvable paradoxes and parables rather than on certainties handed down as law. As in Christian parables, the rewards might appear unjust and the ends unclear, but the method increases the chances that both author and hero will genuinely learn from the process of defining one another. Incarnation - which is delimitation - always means increased vulnerability. When polyphonic authors "come down to earth" and address their creations not vertically but horizontally, they are designing their characters to know, potentially, as much as authors know. Such authors frequently craft a hero of whom they say: "he has to do that, but I do not know why."

To strengthen this reciprocal relation, Bakhtin claims, Dostoevsky designs as the hero of his novels not a human being destined to carry out a sequence of events - that is, not a carrier of some pre-planned "plot" - but rather an idea-hero, an idea that uses the hero as its carrier in order to realize its potential as an idea in the world. The goal then becomes to free up the hero from "plot," in both the sinister and humdrum sense of that word: from all those epic-like storylines that still clung to the novel with their routinized, and thus "imprisoned," outcomes, and also from events in ordinary, necessity-driven, benumbing everyday life. For events - as the biographies of both Bakhtin and Dostoevsky attest - rarely made you free. Bakhtin all but suggests that we leave this pleasant illusion to Count Leo Tolstoy (one of the few great writers against whom Bakhtin actively polemicized), an aristocrat to the manor born who loved life's delightful round of rituals, could afford to lose himself in it, developed an anguish of guilt about it, and came so powerfully to distrust language, that surrogate for action. Instead of unreliable events, Dostoevsky invites his heroes and readers to experience the richer, more open-ended discriminations and proliferations of the uttered word, in a context where all parties are designed to talk back. 
To be sure, in choosing to structure works in this way, the polyphonic author is still authoring heroes and still "writing in" their stories. But by valuing, above all, an open discussion of unresolvable questions, such an author writes them into a realm of maximal freedom.

Polyphony brings further benefits. Once the grip between hero and plot is loosened, and once a dialogue of ideas (rather than a mass of improbable exotic adventures) becomes the common denominator between author, hero, and reader, more space opens up for the reader. Readers can participate actively in the narrative - which is to say, non-vicariously, on an equal plane, with the same equipment. A novel of ideas is less readily escapist or voyeuristic than other types of novels because its most exciting ingredient is thought, and there, willingly or no, we are all equal communicants. (Or as Bakhtin seems to be suggesting, no matter how crippled, constrained or impoverished our lives or bodies may be, we can all always listen in and contribute a response; in this resides Bakhtin's rough democracy.) In terms of their potential to communicate on shared ground, ideas are simply richer than experiences. Dostoevsky's working notebooks testify to his continual surprise at the turns his novels were required to take, in order to accommodate the unexpected growth in ideas that were carried — and tested verbally - by his characters.

According to Bakhtin, the polyphonic hero was Dostoevsky's first great contribution to the art of the novel. His second contribution was to a theory of language. Inside every word, Bakhtin maintained, there is a struggle for meaning, and authors can adopt various attitudes toward this struggle. They can choose to cap or muffle the dialogue, discouraging all outside responses to it, and thus employ the word monologically. Or they can emphasize the word's so-called "double-voicedness," by exaggerating one side (as in stylization); or by pitting two or more voices against one another while rooting for one side (as in parody); or, in a special, highly subtle category Bakhtin calls "active double-voiced words," an author can work the debates inside a word so that the parodied side does not take the abuse lying down but rather fights back, resists, tries to subvert that which is subverting it. Dostoevsky was exceptionally skilled at portraying this final, crafty type of word.

These two innovations - the "fully-weighted hero" who signifies alongside his creator, and the "dialogic word within a polyphonic design" - make up the theoretical core of the book on Dostoevsky. Bakhtin specifically declines to deal with the actions of Dostoevsky's heroes - all those scandals, rumored rapes, suicides, murders, instances of child abuse, 
as well as the sacramental moments of conversion and transfiguration. He also refuses to discuss the specific (and often quite unsavory) content of Dostoevsky's ideas, full of paradoxical wisdom and extravagant generosity but also no stranger to sadism, Russian chauvinism, reactionary politics and psychic cruelty. Bakhtin sticks to formal matters. "Miracle, mystery, and authority" - the three keys that will unlock the world, according to Ivan Karamazov's Grand Inquisitor - get no attention at all in Bakhtin's book on Dostoevsky.

Curiously, we do not know if this elegant formal exegesis is in fact the book that Bakhtin really wanted to write. Near the end of his life, he confessed to his close friend and disciple Sergei Bocharov that in his work on Dostoevsky he had been unable to "speak out directly about the most important questions...the philosophical questions that tormented Dostoevsky his whole life, the existence of God. In the book I was forced to prevaricate, to dodge back and forth continually. I had to hold back all the time. The moment a thought got going, I had to break it off."1 But however Aesopian and self-censored the text might be in its two editions (1929 and 1963), Bakhtin made his peace with what had survived. Unlike Tolstoy, he was no utopian. When asked at the end of his life if the Good would triumph, he answered: "Of course, not."2

For Western readers, the idea of polyphony was at first simply an enigma. How can created characters "create" themselves? Does not the polyphonic author abdicate responsibility for the finished whole of a literary work? As a literary strategy, polyphony was conflated with dialogism, heteroglossia, voice-zones, chronotopic analysis - all those now-fashionable catchwords that Bakhtin had devised only later, in the 1930s, to apply to novels in general, not to the prior (and much more restricted) subset of polyphonic novels. But then there appeared on the scene, in Russia and in the West, critics of polyphony and of its later offspring, "dialogism" - who did not like them at all. Not for themselves, not as metaphors for human freedom, and not as insights into the workings of Dostoevsky's novelistic masterpieces.

1 S. G. Bocharov, "Ob odnom razgovore i vokrug nego," Novoe literaturnoe obozrenie 2 (1993): 70-89, esp. 71-72; English translation (flawed) by Stephen Blackwell, ed. Vadim Liapunov, "Conversations with Bakhtin," PMLA 109, no. 5 (October 1994): 1009-1024, esp. 1012.

2 G. Pomerants, “'Dvoinye mysli' u Dostoevskogo” [1975]. Otkrytost' bezdne: Vstrechi s Dostoevskim (Moscow: Rosspen, 2003), 173. 


\section{Can polyphony exist? If so, does it apply?}

The first complaints against Bakhtin's image of Dostoevsky concerned quite simply its appropriateness to its subject. Were polyphony and doublevoicedness in fact part of Dostoevsky's design? Did the novelist intend the sort of openness for his plots and autonomy for his heroes that Bakhtin claims? There seems to be a strong "authority principle" in Dostoevskyand especially in his final novel, The Brothers Karamazov — that pointedly resists the decentering impulse. ${ }^{3}$ I sample here only one critic's case. In 1989, Yuri Kariakin, Dostoevsky scholar and political gadfly of Solzhenitsyn's generation, published a 600-page book entitled Dostoevsky and the Brink of the Twenty-first Century, in which he took his good friend Mikhail Mikhailovich gently to task. ${ }^{4}$ Polyphony is a faulty hypothesis, Kariakin argues, because it concentrates solely on verbal dialogue and its current of ideas, tending to ignore the effect of fully-embodied scenes. (Dostoevsky was a great master at imagining the scene; and it is in this sense, we might add in support of Kariakin, that Dostoevsky is a "dramatist" - not in the trivial literal sense that his novels can be reduced or adapted to stage or screen, which has proved a far riskier enterprise.) Words come and go, taking pleasure in their own eloquence and ambiguities. But Kariakin insists that in his major scenes, Dostoevsky always included a silent "finger pointing at the truth." The "double-voiced word" [dvugolosoe slovo], which Bakhtin recommends as an interpretive unit for the novel, should thus be replaced by a "triplevoiced word" [trekhgolosoe slovo], with the word's third voice assigned permanently to Dostoevsky as author and, in this special moral sense, stage director. For Bakhtin is wrong, Kariakin contends, when he suggests that self-consciousness is the hero of Dostoevsky's novels. Self-deception is the hero - and all that polyphonic obfuscation, those thought experiments and the endless proliferation of alternatives, all those compulsive storytellers and chatterers, are designed by their author not to provide the major heroes with invigorating, open-ended options but rather to thicken and

3 For the classic Russian argument, see V. E. Vetlovskaia, Poetika romana "Brat'ia Karamazovy" (Leningrad: Nauka, 1977); for a pioneering attempt to use Bakhtin as an aid in interpreting that novel's structures of faith and authority, see Nina Perlina, Varieties of Poetic Utterance: Quotation in The Brothers Karamazov (Lanham, MD: University Press of America, 1985).

4 Yuri Kariakin, Dostoevskii i kanun XXI veka (Moscow: Sovetskii pisatel', 1989), 649. The "triple-voiced word" is discussed on pp. 26-30; the case against consciousness and for self-deception as the "hero" of Dostoevsky's novels on pp. 69-72. 
darken the texture of the work, to increase the obstacles and to test the heroes on their conflicted way to the truth. ${ }^{5}$

Kariakin's reservations on the structural plane are one type of complaint against polyphony. Other skeptical readers have applied the acid test to which every strong critic must submit, namely: are the feelings and reactions we experience when reading Bakhtin on Dostoevsky at all compatible with our feelings upon reading Dostoevsky himself? ${ }^{6}$ At issue here are not merely morally repugnant plots or themes. In Problems of Dostoevsky's Poetics, we repeat, Bakhtin deliberately excluded considerations of ethical content, limiting himself to the workings of language. He remained consistently formalist in his reluctance to pass judgment on the ideology and virtue of Dostoevsky's plots. But remarkably, given its focus on the word, Bakhtin's book also does not address any ethical or metaphysical problems in the formal realm of language. Consider, for example, his treatment of Notes from Underground. The Underground, where consciousness is everything and where words never stick to deeds, is a deconstructor's paradise by postmodernist criteria. As we know, Dostoevsky considered it a wholly godless place; he intended its chatter to be read not simply as misguided or futile but as demonic, and he lays bare its dynamics with ice-cold satire. ${ }^{7}$ Bakhtin does acknowledge that "underground" discourse is dead-ended, a perpetuum mobile and vicious circle. But ultimately that grim voided place represents for him a fundamentally positive principle, even if taken in this instance to unfortunate extreme: the virtue of "unfinalizability." For the logic of the Underground guarantees all speakers who reside there the right to postpone the final verdict - and to deliver a supplementary word on themselves that others do not, and in principle cannot, know.

5 For a more comprehensive discussion of Dostoevsky and the Brink of the 21st Century and the reservations it raises about Bakhtin's reading of the novelist, see Caryl Emerson, "The Kariakin Phenomenon," Common Knowledge 5, no. 1 (Spring 1996): 161-78, esp. 166-69, 173-75.

$6 \quad$ For two preliminary surveys, see Caryl Emerson, "Problems of Baxtin's Poetics," Slavic and East European Journal 32, no. 4 (Winter 1988): 503-25; and Caryl Emerson, "Word and Image in Dostoevsky's Worlds: Robert Louis Jackson on Readings That Bakhtin Could Not Do," in Freedom and Responsibility in Russian Literature: Essays in Honor of Robert Louis Jackson, eds. Elizabeth Cheresh Allen and Gary Saul Morson (Evanston: Northwestern University Press and Yale Center for International and Area Studies, 1995), 245-65.

7 The best account of the ideology of Notes from Underground remains that by Joseph Frank, in ch. 21 of his Dostoevsky: The Stir of Liberation, 1860-65 (Princeton: Princeton University Press, 1986), 310-37. In a lengthy footnote (p. 346), Frank notes his reservations about Bakhtin. 
The Underground viewed not as trap but as "aperture" is only one peculiarity of reading Dostoevsky through a Bakhtinian lens. Other critics have noted that Bakhtin's passion for the horizontally-cast dialogic word often comes at the expense of Dostoevsky's more vertical gestures, those leaps into iconic or transfigured time-space that provide the great novels with their crowning moments of personal conversion or collective Apocalypse. ${ }^{8}$ Bakhtin has little sense of the sublime. With equal fastidiousness he avoids absolute bliss and absolute horror. He never mentions Dostoevsky's quasi-fictionalized prison memoirs Notes from the House of the Dead, for example, nor does he make reference to that gallery of tortured and silenced children that are so crucial a part of Dostoevsky's symbolic universe. Part of the problem, surely, is that those silenced victims cannot, or do not, talk (although they can be talked about); and left solely with the ugly, silent material aftermath of a violent event - a corpse, a suicide, an atrocity that leaves us speechless - Bakhtin as a reader of Dostoevsky's world seems somewhat at a loss. What is strange here, we should note, is not Bakhtin's unwillingness to be mired down (as so many have been) in Dostoevsky's cruel, crowd-pleasing gothic plots; such plots, after all, were the conventional and thus almost invisible raw material of the nineteenth-century urban novel. More significant is the fact that Bakhtin also has almost nothing to say about the centrally important, affirmative, "godly" dialogues - if they happen to be wordless. Among these crucial mute scenes are Raskolnikov and Sonya on the banks of the Siberian river in the Epilogue of Crime and Punishment; Prince Myshkin's meaningless babble as he embraces a silent Rogozhin over Nastasya Filippovna's corpse at the end of The Idiot; and-most famously-Christ kissing the Grand Inquisitor after having listened, in silence, to that brilliant monologic harangue. ${ }^{9}$ In Bakhtin's readings, it seems, only the interaction of one verbal utterance with another verbal utterance can be adequate to the most subtle and multilayered communication. By definition, this interaction opens up new potentials. The possibility that verbal dialogue might actually drain away

8 See, for example, David M. Bethea, The Shape of the Apocalypse in Modern Russian Fiction (Princeton: Princeton University Press, 1989), esp. "The Idiot: Historicism Arrives at the Station," 103-04; and Malcolm V. Jones, Dostoyevsky after Bakhtin: Readings in Dostoevsky's Fantastic Realism (Cambridge: Cambridge University Press, 1990).

9 Bakhtin did make these suggestive jottings late in life, however, in a passage devoted to Dostoevsky: "The unuttered truth in Dostoevsky (Christ's kiss). The problem of silence. Irony as a special kind of substitute for silence." See "From Notes Made in 1970-71," in Speech Genres and Other Late Essays, eds. Caryl Emerson and Michael Holquist, trans. Vern W. McGee (Austin: University of Texas Press, 1986), 148. Henceforth SpG 86. 
value, or flatten out a subtlety, or be so subject to terror and constraint that it depreciates into outright fraud, is not for Bakhtin a theoretically serious issue. On principle, he seems reluctant to project a human being so evil, weak, indifferent or exhausted that he or she can no longer listen to, or author, a useful word.

Let us now move into even more critical and suspicious corners of the Bakhtin industry. On the occasion of the thirtieth anniversary of Problems of Dostoevsky's Poetics, the editorial board of the Belarus Bakhtin journal Dialog. Karnaval. Khronotop distributed questionnaires to two dozen eminent scholars, soliciting their opinions on the role of the book and its author in the history of Russian thought. Returns began to appear in $1994 .{ }^{10}$ Although the proper jubilee praises were sung, several of the scholars polled were clearly irritated at Bakhtin's single-minded pursuit of polyphony in every corner and at any cost. Polyphony was judged inadequate to Dostoevsky's complexity not only for the old reason - that the voice of the author must always be firmer and more primary than that of the created heroes - but for newly legitimated religious reasons as well. As one contributor put the issue bluntly, "the authoritativeness of the author's word... relies on the authority of Christian truths, whose conscious transmitter and preacher Dostoevsky was" (7-8). Unlike the uglier ideologies of the modern period, we are told, religious faith "could not be a monologism." Georgii Fridlender pursued the Christian line further. He classified the Dostoevsky book alongside works by Vyacheslav Ivanov and Nicolas Berdiaev as a prime text in Russian Orthodox "personalism" (14) - although he added that Bakhtin was perhaps too marked by the binary oppositions fashionable in his era, which lent his work a structural elegance but also a certain rigidity. By so stubbornly insisting on polyphony, "Bakhtin, paradoxical as it seems, was extremely monologic and didactic" (15). The genre theorist Vladimir Zakharov was least accommodating of all. Bakhtin "wanted to think freely in a totalitarian society" and yet was destined to work out his major ideas in resistance to Stalinist oppression. Under those conditions, Bakhtin came up with some brilliant formulations - but whatever he did not wish to think about, no matter how central to literary scholarship (Zakharov has in mind his own area of research, the Dostoevskian narrator), he simply ignored. "Without this resistance [to Stalinism], however, he would scarcely have

10 “Anketa «DKKh»," Dialog. Karnival. Khronotop 1 (1994): 5-15. Page references given in text. Henceforth this Bakhtin journal will be referenced in notes as DKKh + volume \# and year. 
been so original a philosopher.... May the Bakhtinians not be offended by what I say," Zakharov concluded, "but in many respects, Bakhtin already belongs to history" (9).

Zakharov's verdict, although addressed to a local forum of specialists, cannot be wholly dismissed. At the Bakhtin Centennial Conference in 1995, not a single paper, by Russians or non-Russians, was devoted exclusively to Bakhtin on Dostoevsky. This did not seem to distress his followers. Many defended Bakhtin's admittedly lopsided reading of the great novelist as simply "illustrative" of something more important - the way Freud, say, had used the literary image of Oedipus to illustrate his powerful hypotheses about the human psyche. Thus, it was felt, Bakhtin should not be subject to potshots from literary specialists. His book had become a classic of criticism, wedded to his personality, and Bakhtin (like any grounded personality) sees certain things as central, other things as peripheral. The precepts of his book had long been considered as magisterial, as grandfatherly and uncontroversial as, say, those of Wayne Booth, Warren and Wellek, Northrop Frye or Frank Kermode.

But let us push the critique further. For there is a group of critics, in Russia and in the West, who find Bakhtin's whole model of polyphony not only untrue to Dostoevsky's primary intentions as a novelist and a thinker, but also inconsistent and somewhat dishonest on its own terms - for psychological and linguistic reasons as well as for ethical ones. These critics are developing an argument that was made forcefully a decade ago by Aaron Fogel, in a fine book on Joseph Conrad entitled Coercion to Speak. ${ }^{11}$ Fogel's point - which overlaps with Leo Tolstoy's — is that dialogue, as Bakhtin invokes it, is not the normal human relation at all. Most human speech, Fogel argues, is forced, awkward, or under constraint. Although dialogue, when it does occur, can at times be a blessing and a relief, the task of making it happen between two people is difficult, dangerous, and (here is the scary, non-Bakhtinian part) often made worse when we try, against all odds and against the interests of the participants, to "talk things out." Conrad was master of this truth. However Bakhtin might package it, Fogel argues, clearly much of the time, for a large number of human problems, dialogue is not a "talking cure."

11 Aaron Fogel, Coercion to Speak: Conrad's Poetics of Dialogue (Cambridge, MA: Harvard University Press, 1985). 


\section{Unsympathetic case studies and suspicious close readings}

In 1994, a postmodernist work of literary criticism was published in St. Petersburg titled Anti-Bakhtin, or the Best Book about Vladimir Nabokov. ${ }^{12}$ Overall the book is impulsive and derivative (we quoted from it briefly in Chapter One, as exemplary of the crasser sides of the Bakhtin backlash) but its author, Vadim Linetsky, does remark tellingly upon one vulnerable area in a dialogic poetics. Linetsky protests that Bakhtin, in his essay "Discourse in the Novel," "reacts rather skeptically to dialogue in the traditional understanding of the word." By "traditional" Linetsky appears to mean all those situations where people simply talk back and forth in good faith - in order to exchange information, give one another cues, reveal their immediate desires, clarify one another's intentions, in short, try to tell the truth as each party understands it at that moment - and thereby resolve, sooner or later, on a course of real action. Linetsky observes that Bakhtin considers such ordinary, practical verbal exchanges to be rather flat and monologic, dismissing them as conceptually trivial and restricting their role to a "compositional" or merely "plot-related" function in the work. Bakhtin does so, Linetsky suggests, because he does not really value practical reallife distance between one person and another - even though all genuinely embodied dialogic exchange must be based on it. Distance is a prerequisite for the effective working of all addressed words, codes, controls and social hierarchies, however; real distance is required for any "materialization of power" in real life. Without a good intuitive sense of these parameters, none of us would ever open our mouths. And, we might add - as an old-fashioned gloss to Linetsky's faintly postmodernist casting of this problem in terms of power - this distance between one person and another is also what enables independence, privacy, and genuine acts of giving, just as it makes inevitable both human loneliness and longing.

Linetsky's reservation could be expanded. As we shall see in Chapter Five, Bakhtin builds both his ethics and his aesthetics around the virtues of "outsideness." But one suspects that Bakhtin would prefer us to be not wholly outside, not all that distant from each other: we should hover around a shared boundary, different but not that different, curious about others but not threatened by them, speaking not (of course) the very same language but enough the same language so as to insure that others hear us and incline 
toward us. Or, as Bakhtin put the matter with disarming simplicity near the end of his life, "the more demarcation the better, but benevolent demarcation, without border disputes." 13 This scenario is indeed inspirational: boundaries between people are to multiply, and yet all lethal disputes are to wither away. But the dynamics here apply to only a tiny fraction of the heroes in Dostoevsky's novels - and not, I wager, to the ones who excite us and strike us as the most deeply human, the ones whose maniacal inner workings we would expect a literary critic to elucidate. Further: these trapped maniacal heroes, more often than not, do not thirst after any fancy double-voiced dialogism, which can create for them only more doubts and confounding options. From within their own unhappy unstable worlds, these heroes simply want to believe in something. They crave to be understood, and they want to be loved.

An unsettling critique of Bakhtin's image of Dostoevsky can indeed be mounted along these lines. One place to ground it would be in Bakhtin's earliest philosophical writings, where he addresses the difference between ethical and aesthetic terrain in a work of art. ${ }^{14}$ An event becomes "aesthetic," in Bakhtin's world, if there is an outside consciousness looking in on the event and embracing it, able to bestow upon the scenario a sense of the "whole." Such an external (and thus aesthetic) position is available to spectators watching, to readers reading, and to an author "shaping." But from within the artwork, that is, from the perspective of the created character who is undergoing a particular pleasure or torment, events are of course experienced as partial, unshaped, cognitively open, ethically irreversible, as matters not of art but of life and death. The hero - or at least the hero in a realistic novel, always Bakhtin's genre of choice - does not feel his own life to be a fiction. Let us apply this early distinction to some scenarios from the Dostoevsky book. It will help us glimpse the mechanism by which Bakhtin, working with such often desperate texts, arrives at his dialogic optimism.

Take, for example, death. Bakhtin turned to the topic often in his writings, and usually in a spirit of benevolent gratitude: death is aesthetic closure, that point where creative memory can begin, the best means for

13 "From Notes Made in 1970-71," in SpG 86, 137.

14 See the opening segments of "The Problem of the Author's Relationship to the Hero" and "The Spatial Form of the Hero": Mikhail Bakhtin, "Author and Hero in Aesthetic Activity," in Art and Answerability: Early Philosophical Essays by M. M. Bakhtin, eds. Michael Holquist and Vadim Liapunov, trans. Vadim Liapunov (Austin: University of Texas Press, 1990), 4-16; 31-46; 73-75. 
making a gift of my whole self to another. As one Polish scholar has summed up this position, Bakhtin devised not a neo- but a "post-humanistic vision of man": if neohumanism takes the individual personality as its reckoning point and thus regrets its passing, Bakhtin, with his insistence that an "I" comes to exist only on the border between itself and someone else, provides us with a model of death that is neither an insult to consciousness nor a blessing to it but, as an event, simply irrelevant. Only that which exists in itself can die. ${ }^{15}$ Thus the grimmer aspects of death - its abyss of silence, non-negotiability, unanswerability, aloneness - that so terrified other Russian writer-philosophers (say, Leo Tolstoy, to whose anxieties Bakhtin seems singularly immune) appear to have persuaded Bakhtin that the whole procedure, being so wordless and so unavailable to my own dying consciousness (my death can exist only for others, not for me), is not worth taking seriously.

This elegant resolution of the problem of our mortality — again recalling the Hellenistic philosophers - was graciously bestowed by Bakhtin on his own hero and scholarly subject, Dostoevsky. In his 1961 notes for the revision of Problems of Dostoevsky's Poetics, Bakhtin remarks that death hardly signifies at all for the great polyphonic novelist. In support of this claim and in contrast to Tolstoy, he points to the fact that "Dostoevsky never depicts death from within [the dying person];" death is an event solely for another, as yet living consciousness, and thus it "finalizes nothing" in the larger realm of the spirit. And why, indeed, should we fear extinction if, as Bakhtin put the matter movingly: "Personality does not die. Death is a departure.... The person has departed, having spoken his word, but the word itself remains in the open-ended dialogue.... Organic death, that is, the death of the body, did not interest Dostoevsky."16

Perhaps it did not. But, one might object, surely the death of the body interests Dostoevsky's characters. And death obsesses precisely those characters who reside in the novels that Bakhtin skirts most widely: the totally ignored Notes from the House of the Dead; the novel Devils, with its brutal arbitrary murders and its travestied Nativity scene (the mother and "illegitimate" son of Shatov's beloved family, who die almost as

15 Dr. J. Wizinska, "Post-humanistic Vision of Man in the Philosophy of M. Bakhtin," in Yazyk i tekst: Ontologiia i refleksiia [Proceedings from a Conference on philosophy and culture held in St. Petersburg, 17-21 1992] (Sankt Peterburg: Eidos, 1992), 320-22.

16 "Toward a Reworking of the Dostoevsky Book," in Problems of Dostoevsky's Poetics, ed. and trans. Caryl Emerson (Minneapolis: University of Minnesota Press, 1984), 290, 300. Henceforth PDP. 
an afterthought in the wake of his murder); The Idiot, with its horrifying incoherence over Nastasya Filippovna's dead body in the final scene; and Dostoevsky's harrowing deathside monologue "Krotkaia" [The Meek One], which unfolds - which could only unfold - over a corpse. In fact, the only death-story that Bakhtin reads in any fullness is the tiny throwaway tale "Bobok," a menippean satire about obscene graveyard conversations carried on by the dead who refuse to die or fall silent. Bakhtin's less sympathetic critics see something disturbing in this pattern of omissions. Is the man so committed to unfinalizable dialogue, to the good we can do others if only we remain outside them and talking to them, that he is indifferent to the physical and ethical world as experienced by Dostoevsky's heroes, to its innerness and breaking points? For surely Dostoevsky, as author, did not intend his absorbed and captivated readers to react to the crisis-laden plots of his novels with bland hope or benign resignation, relegating those ultimate life-and-death questions to some ephemeral dialogue-in-the-sky; he was counting on horror. Some epiphanic vision or shock of revelation must precede a conversion. The unfinalizability is only in Bakhtin.

Death, then, is similar to aesthetic wholeness in that it, too, is the product of a dialogic situation. It also requires an outsider, or a socium, to bestow it. In Bakhtin's exegesis, this bestowal is simply not felt as murder. In fact, Bakhtin is as curiously untroubled by dying as he is by the possibility that outsideness will turn alien or hostile - although the best students of Dostoevsky routinely have found those two anxieties central. Gary Saul Morson, for one, has argued cogently that for Dostoevsky, an astute student of the fundamentally social vices, the state of being "external to" and in social relation put one at great moral risk. ${ }^{17}$ As the novels demonstrate, we are indeed indispensable to one another - but for reasons that give no cause for rejoicing. Sociality is scandal space, the site of voyeurism. ("In Dostoevsky's novels," Morson writes, "suffering, shame, torture and death usually take place before a crowd of spectators who indulge in the quintessential social act of gaping. In Dostoevsky, the first sign of our essential sociality is that we are all voyeurs.... Nobody had a deeper sense of the social as an arena of gratuitous cruelty.") Reacting to this truth, several American scholars are now supplementing Bakhtin's "aesthetic" interpretations of Dostoevsky with darker ethical correctives that work with more than just words.

17 Gary Saul Morson, “Misanthropology," New Literary History 27, no. 1 (Winter 1996): 57-72, esp. 62, 71 . 
Among the thinkers most usefully invoked is Emmanuel Levinas and his philosophy of human obligation arising from eye-to-eye contact with a living, suffering - even if wholly silent - face. ${ }^{18}$

Must a Dostoevskian "idea-person" be at core a talking person? Most critics who are unsympathetic to Bakhtin are made uneasy by this question. Consider Raskolnikov. Words come out of his mouth - but what might well be taking place at such moments is not a response to another but a lunatic inner monologue that has been (for lack of genuine empathy, interest, or lived experience on Raskolnikov's part) simply embellished and exacerbated by other people's utterances. For the most powerful instinct in Raskolnikov, considered as a human being and not just as a repository for words or ideas, is always to stop talking with "real others" as soon as possible, to detach the words uttered by those others from the experience or the truth that had given rise to them in their own contexts, and to start using those words to rewrite the world according to his own prior and fixed notions of it. Dostoevsky, by all the indices we have, was acutely aware of this dynamic - and he might have intended his gifted but appallingly selfabsorbed Raskolnikov to be perceived, if anything, as monologic because of it. After all, Raskolnikov was created after the Underground Man and is a refinement upon his type. Unlike that earlier, more overtly grotesque and thus far less threatening image, however, Raskolnikov has high intelligence, beauty, boldness, the ability to act. But he shares with his predecessor an inability to listen.

Among those who might have agreed with this hypothesis is the eminent literary scholar and Bakhtin's slightly younger contemporary, Lydia Ginzburg. One of Russia's best readers of Proust, Herzen and Tolstoy, Ginzburg was drawn to explicate literary worlds that were as hospitable to the Tolstoyan hero as Bakhtin's world was structured to wall that type of hero out. Central to the Tolstoyan world was the concept of "conversation"

18 See Leslie Johnson, "The Face of the Other in Idiot," Slavic Review 50, no. 4 (Winter 1991): 867-78; and Val Vinokurov's trenchant critique and expansion from a Levinasian perspective in his "Dostoevsky's Deaths: Towards a Post-Bakhtinian Reading of Demons" [unpubl. ms., 1996]. Vinokurov writes of Myshkin: "The Prince is simply profligate toward the face, and thus unable to live with the politics, the agony and violence of choosing between faces that justice demands when I and the other are not alone in the world. His departure is Christ's failure on earth. Leslie Johnson is too ready to fill in the blank of Dostoevsky's doubts by insisting so wholeheartedly on Myshkin's potential. The world does not fail Myshkin. The world cannot fail. Only the individual can fail against the resistance of the world. He can also, unlike Myshkin, succeed." 
[razgovor], an uncomfortable, stressed, easily embarrassed form, rarely honest or articulate in its adult social manifestations and driven by impulses (vanity, lust, ambition) far more raw than pure ideas. Ginzburg is not sympathetic to Bakhtin's notion that Dostoevsky's characters, being "idea-persons" in pursuit of higher concepts, are thereby less selfish. "Tolstoy discovered the first principles of shared spiritual experience as it relates to the contemporary person, and this person is not even aware that he conceives of himself in Tolstoyan terms, that in fact he has no other choice," she writes in her 1960s book On Psychological Prose. "To be sure, this character finds it more interesting to conceive of himself in Dostoevskian terms, since doing so allows him to focus attention on himself."19 Ginzburg and other non-Bakhtinians would see polyphony as a rapid, profound, and profoundly selfish internalization of relationships - a removal of human relations from the realm of responsible outer actions (or inter-actions) because that space involves commitment to unpredictable or unmanageable Others, into the safer realm of inner words and domesticated verbal images of the other. For a reciprocal act of communication is brought about not merely by thinking of another, nor by carrying on a mental conversation with another at one's own leisure and convenience.

Bakhtin suggests that polyphony in a novel serves to put the unfinalizable idea on trial. But in ethical life, an unfinalized thing cannot be tested or put on trial. Trials follow completed deeds; they have verdicts, sentences, punishments. People are acquitted, locked up, shot. In benign contrast to the real courtroom trial, ideas in inner dialogue always have loopholes and a chance to be re-uttered. Bakhtin, it is true, intends the comparison between Dostoevsky's novel and polyphony as "a graphic analogy, nothing more" ( $P D P, 22)$. But the term polyphony, which Bakhtin often employs alongside another musical metaphor, "counterpoint," is surely meant to evoke, at a minimum, the image (or sonority) of a multiply harmonized texture composed of discrete, interwoven strands, receptive and inviting to others. As we have seen, skeptics would sooner call it a soliloquy of the isolated, narcissistic self. Furthermore, it is a soliloquy that, by its very dynamics and the doors it shuts behind itself, beckons

19 Lydia Ginzburg, On Psychological Prose, trans. and ed. Judson Rosengrant (Princeton: Princeton University Press, 1991), 243. Translation somewhat adjusted. It seems plausible that this somewhat arch retort is Ginzburg's response to Bakhtin's remark, in Problems of Dostoevsky's Poetics, that "all of Dostoevsky's major characters, as people of an idea, are absolutely unselfish, insofar as the idea has really taken control of the deepest core of their personality" (PDP, 87). 
the speaker toward violence and murder. The revisionists insist that Dostoevsky, who was not at all naive about the difficulties of honest dialogue, would concur. What Dostoevsky was parodying, Bakhtin took for authentic coin.

According to the revisionist critics, then, such polyphonic manipulation of ethical choice - rendering it reversible and always "inner" - cannot be the major mechanism at work in Dostoevsky's novels. It cannot, because Dostoevsky is himself a discriminating moralist who arranges matters in his fiction so that major heroes are run not by ideas, as Bakhtin claims, but by doubt. These heroes do not wish to be polyphonically "free" of ultimate commitment. Rather the opposite is true: they want desperately to believe, and they cannot. They examine options in order to be rid of them, to move forward into the deed, not merely for the pleasure of elaborating more options. About passionate desire and passionate doubt - the predominant fuel of real, elusive, needful people, who change over time - Bakhtin, in the opinion of these critics, hasn't a clue.

Is this critique just? Again, it depends - quite literally - upon one's point of view. For what Vadim Linetsky, Yuri Kariakin, Lidia Ginzburg, and others who take Bakhtin seriously but with a severely critical eye have done in their analyses of polyphony is to consider a given experience or event in Dostoevsky's texts not "externally" - as a reader, philosopher, scholarly critic - but from the simple trapped perspective of the created hero, whose freestanding interests Bakhtin claims to champion. The method has merit, I might add, because ordinary untutored readers of novels (the audience for whom Dostoevsky actually wrote) identify in this way instinctively; it is one of the great pleasures of the genre. Put yourself in the hero's place. The first thing you will insist upon is that consciousness alone does not make a biography. My plot, after all, is my life. I do not want to be liberated from it. And least of all do I wish to be liberated by an author who values only my verbal residue and my trail of coherent ideas, not my decisions, unspeakable losses and irreversible events. Dialogic communication, if it aspires to an ethical position, must mean more than simply "Leave me alone to think about what you just said."

The non-Bakhtinians insist that Dostoevsky was fully aware of the solipsism in any "dialogue of ideas" that only pretends to fulfill a communicative function. For true dialogue is measured by many criteria - precision of expression, proper timing, impact on the listener, subsequent modification of behavior - and makes use of various instruments, of which words are only one. (In 1996, one practicing psychotherapist in the New Russia concluded 
an essay on Bakhtin and family counseling with a section whose title was surely inspired by Christ's response to the Grand Inquisitor: "Silence as the heights of dialogue." ${ }^{20}$ ) No reader would dispute that novelistic worlds must be reached through words; the novel is a verbal form. But once we are inside that world, arguably the real power of the genre is in the interpersonal space, the scene called forth, the entire complex that we (along with the characters) see and feel, not only what we hear, speak and think. Therefore these critics do not agree with Bakhtin when he states, in a passage written just prior to revising the Dostoevsky book, that "language and the word are almost everything in human life."21 They sympathize, rather, with Alexei Kirillov, the monomaniacal, weirdly inarticulate nihilist in Dostoevsky's The Devils and one of that novel's few attractive, kindly and honest figures, when he says to his would-be murderer in the final conversation before his suicide: "All my life, I did not want it to be only words. This is why I lived, because I kept on not wanting it. And now, too, every day, I want it not to be words." 22

Curiously, some centennial rethinkings of Bakhtin's Dostoevsky book endorse this polemic against logos-centric dialogism - but in an effort to redeem, rather than to undermine, Bakhtin's interpretation of Dostoevsky. In a 1995 paper, the Moscow philosopher Natalia Bonetskaia defended Bakhtin's second edition, and particularly its massive menippean satire insert, as a belated discovery on Bakhtin's part that the 1929 study was indeed inadequate to the darker sides of his subject. ${ }^{23}$ The rosy, sentimentalRomantic view of reciprocal dialogue that governs the 1929 original version was simply too partial a picture to be allowed to stand, she argues; Bakhtin eventually wanted to "get at more than merely the poetics" (30). He felt

20 T. A. Florenskaia, "Slovo i molchanie v dialoge," DKKh 1 (1996): 49-62, esp. "Molchanie kak vershina dialoga," 60-62. Remarking on the unexpected ability of therapists to sense quickly the sort of language that will penetrate the most recalcitrant subject and have an effect, she then notes that dialogue requires not verbal language per se but only an act in which one's "dominant orientation is toward the interlocutor;" only under conditions of "the most intimate spiritual closeness" is silence between two people, "understanding without words," possible.

21 "The Problem of the Text in Linguistics, Philology, and the Human Sciences: An Experiment in Philosophical Analysis" [1959-61] in SpG 86, 118.

22 Fyodor Dostoevsky, Demons, trans. Richard Pevear and Larissa Volokhonsky (New York: Knopf, 1995), Part Three, II (“A Toilsome Night"), 615.

23 N. K. Bonetskaia, "K sopostavleniiu dvukh redaktsii knigi M. Bakhtina o Dostoevskom," Bakhtinskie chteniia, vyp. I, Materialy Mezhdunarodnoi nauchnoi konferentsii, Vitebsk, 3-6 July 1995 (Vitebsk, Belarus: 1996). 
obliged to address the real pathos and perverse intonation of Dostoevsky's world. And what, Bonetskaia asked, could be more hysterical, chaotic, hellish, anti-dialogic than the spirit of carnival? If dialogue is "personality, reason, freedom, the realm of meanings, the light of consciousness and perhaps of Logos," then carnival is the existential void, the appearance of Dionysian chaos, a darkening of reason and the triumph of the elemental unconscious, "the night of human nature" (28). As shall become clear in the following chapter, such a reading - although ingeniously motivating the move from the first to second edition of the Dostoevsky book - requires a demonic view of carnival that Bakhtin's own demonstrably passionate attachment to the concept very poorly accommodates.

Can a balance on dialogue be achieved between the Bakhtin idolaters and the demolitionists? By judging Bakhtin's account of Dostoevsky negligent in this matter of responsible relationships with real others in real time, the anti-Bakhtinians raise substantial questions about the ethical center of his entire enterprise. Does dialogism affirm self and other, or efface both sides? Scholars at work on Bakhtin's Silver Age context have hinted at links between his thought and Solovievian and Symbolist experiments of the Russian Decadent period - which were, after all, not that distant from the young Bakhtin in Petrograd. Leading poets of the pre-war period were experimenting with non-consummated marriage, homoerotic utopias, metaphysical equivalents of family, and extravagant projects for transcending death. Under the influence of Platonic philosophy, they advertised a wide variety of self-absorbed, autonomous, sterile structures for intimate love. ${ }^{24}$ Can it be said that Bakhtin's self-other paradigms belong to that company?

Let us turn to Bakhtin's own self-evaluation. In 1961, he summed up Dostoevsky's major innovations in the art of the novel with the following three postulates. ${ }^{25}$ First, Dostoevsky is credited with structuring a "new image of a human being that is not finalized by anything (not even death)" - to which Bakhtin adds, with his characteristically inspirational stoicism, that such a human image is unfinalizable because "its meaning cannot be resolved or abolished by reality (to kill does not mean to refute)." Second, Bakhtin claims that Dostoevsky devised a way to represent,

For an excellent discussion, see Olga Matich, "The Symbolist Meaning of Love: Theory and Practice," in Creating Life: The Aesthetic Utopia of Russian Modernism, eds. Irina Paperno and Joan Delaney Grossman (Stanford: Stanford University Press, 1994), 24-50. 
through words, the "self-developing idea, inseparable from personality." And third, Bakhtin honors Dostoevsky as the writer who discovered dialogue "as a special form of interaction among autonomous and equally signifying consciousnesses." How much of this three-part assessment is still intact?

The first and third "discoveries" have come under sustained attack. The most articulate opponents of Bakhtin today argue that Dostoevsky did indeed believe that "to kill was to refute" — and to neglect the importance of all the killing that goes on in his novels is simply to misread the novels. They have also argued that interaction within those novelistic worlds does not take place among "autonomous and equally signifying" voices: it takes place between mortal bodies. And the interaction there is either deadly political and manifestly unequal, as when Raskolnikov murders an old woman with an axe and Pyotr Verkhovensky stalks Kirillov with a gun, or - if we are dealing with polyphonic dialogue rather than with murder - the interaction, more often than not, is narcissistic, isolating, and indifferent to the real world (to death in the first instance, but also to any vulnerability or desire coming from, or directed toward, a needful other). Dostoevsky saw this misuse of language and parodied it. He was far more attuned to the healing effects of non-verbal communication - silence, icons, genuflections, visual images - than he was to the alleged beneficent effect of words. And thus, as regards the second achievement credited by Bakhtin to Dostoevsky, the "self-developing idea" fused to personality and freed from the distractions and humiliating constraints of plot: this has seemed to many readers more a recipe for monologue than for dialogue. I have my idea, you have yours, and we will feed them to each other without listening to each other until each of our ideas has ripened and the novel is over.

This critique has been taken - unjustly but provocatively — to an even more sinister extreme by one group of Russian postmodernists, the Conceptualists. They see something suspicious and evasive in the obsession with "dialogue" and "naming" that marks so many Russian philosophers, in whose ranks they now enroll Bakhtin. ${ }^{26}$ In theory, they say, Bakhtin

26 Speaking of Dostoevsky, the Conceptualist artist Ilya Kabakov has remarked that the incessant chatter which fills the novels does not "test an idea" at all; those endless debates succeed only in drawing in and implicating the reader to such an extent that "the thread is lost," the chains of debates grow to "monstrous length," and all parties forget what is at stake. Il'ia Kabakov, Zhizn' mukh / Das Leben der Fliegen (Kölnischer Kunstverein, n. d.), 128. 
might have believed that "to exist [authentically] means to communicate dialogically," but in practice this dialogic utopia ends up as a "neurosis of incessant talk" that pretends to provide options for real people trapped in real places but in fact makes it altogether too easy and attractive for us to separate words from any ordinary real-life referents. Conceptualists claim there is a venerable Russian tradition of putting words in circulation for their own sake - and its genealogy reads like an honor roll of Russian literature. The starting point is Nikolai Gogol, whose genius created unprecedentedly palpable reality out of waxy masses of words and sounds not moored to any object. The brooding talkers and dreamers of Dostoevsky and his devoted servant Bakhtin are two intermediary steps. The proud inheritor, they insist, is Stalinist Russia. As their chronicler Mikhail Epstein has noted, the autonomy of the uttered word in Russia did not further the interests of civil liberty or freedom. Instead, it lent a sort of voodoo authenticity to fantasy constructs, including those fantasies that could inflict a great deal of public harm; "it was the hidden assumption of the Soviet system, after all, to give the status of absolute reality to its own ideological pronouncements." 27

The psychoanalytic critic Aleksandr Etkind provides a concrete example. "Let us imagine Soviet interrogators, contemporaries of Vygotsky and Bakhtin," he writes in his 1996 collection of essays on the intellectual life of Russia's Silver Age titled Sodom and Psyche. "What they needed was the fact of an accused person's confession, because the other extra-verbal reality did not exist. Whether or not the accused was lying, slandering himself, doing it under threat or in order to bring an intolerable torture to an end - all that was unimportant, because something other than words was required in their account: feelings, acts, situations.... In the Soviet person, there is nothing that is not expressed in words. Except for words,

27 Epstein has thus argued the Conceptualist case contra Bakhtin, drawing on one of their prominent practitioners, Ilya Kabakov: "For Bakhtin, the dialogic relationship is the only genuine mode of human existence: addressing the other through language. For Kabakov, this obsession with dialogue bears witness to the lack of any relationship between words and a corresponding reality... Kabakov sees this inclination for verbosity as a symptom of Russia's fear of emptiness and the implicit realization of its ubiquity... For Bakhtin, to exist authentically means to communicate dialogically, which allows us to interpret Bakhtin himself as a utopian thinker seeking an ultimate transcendence of human loneliness, alienation and objectification. Kabakov advances a postmodern perspective on this dialogical utopia, revealing the illusory character of a paradise of communication..." Mikhail Epstein, "The Philosophical Implications of Russian Conceptualism," paper delivered at AAASS (Washington DC), October 1995. 
nothing exists." ${ }^{28}$ Thus do the Conceptualist critics and their ideological allies wish to destalinize Russia by fighting against the proliferation of ecstatic, indestructible, floating words and ideas, the sort of words that during the Communist period almost boasted of their independence from the world as it really was. Such words, precisely because of their immortality, are exempt from judgment and can be irresponsible, promiscuous, lie-bearing. Thus the Conceptualists build up and smash images, analyze museums and bombsites, compile lengthy treatises documenting the Life of the Housefly. Far more ethical than to work with the ever renegotiable poetic word, they argue, is to acknowledge a perishable world full of mortal, destructible, fully ordinary and thus precious events and things.

We have now come full circle. The polyphonic Bakhtin, freedom-fighter and champion of the individual voice, has become solipsistic Bakhtin, Stalinist fellow-traveler. This is surely a monstrous and untrue trajectory. We now return, as we close down this first problematic reassessment of the legacy, to a defense of Bakhtin — who remains, after all has been rethought and reargued, one of the most powerful thinkers of our century.

\section{"The Torments of Dialogue": in defense of Bakhtin}

In a 1994 issue of Filosofskie nauki, to honor the upcoming centennial, the literary scholar and philosopher P. S. Gurevich published a lengthy (and rather negative) review of leading American Dostoevsky scholarship under the title "Muki dialoga" - the torments of dialogue. ${ }^{29}$ He deems much Western work that draws on Bakhtin to be rather primitive, in part because it "ignores the polyphonic nature of polyphony itself" and too often endorses some monologic slice of an idea that is then allowed to regiment and dictate the whole. The polyphonic principle should not be viewed as simply one more method for analyzing artistic practices, Gurevich concludes.

28 Aleksandr Etkind, Sodom i Psikheia: Ocherki intellektual'noi istorii Serebrianogo veka (Moscow: ITs-Garant, 1996), 296.

29 P. S. Gurevich, "K 100-letiiu so dnia rozhdeniia M. M. Bakhtina: Muki dialoga," in Filosofskie nauki 4-6 (1994): 15-31. The scholars discussed are R. L. Cox [Between Earth and Heaven: Shakespeare, Dostoevsky and the Meaning of Christian Tragedy]; Robert Belknap [The Structure of "The Brothers Karamazov"]; Gary Saul Morson [The Boundaries of Genre: Dostoevsky's "Diary of a Writer" and the Traditions of Literary Utopia]; Joseph Frank [Dostoevsky: The Years of Ordeal, 1850-1859]; and Robert Louis Jackson [The Art of Dostoevsky: Deliriums and Nocturnes]. Further page references in text. 
"Dialogue, polyphonism are passwords to a new cultural paradigm — which, with difficulty and through all the sluggishness, monologism and torments of communication, is cutting itself a path" (31). This sense of dialogue's great difficulty, the enormous pressure and precision required to carry it out honestly, is a useful preface to any understanding of Bakhtin's central concept. For the Conceptualists are wrong about Bakhtin and words. Although Bakhtin was certainly pro-language - he was, after all, a philosopher of language, that was the subject of his research - he did not share any of the transfigurational attitudes toward the word endorsed by Symbolists, avantgarde Futurists, and later by the state-sponsored Socialist Realists. He did not believe that one could subdue nature through words; he was no proponent of the theosophist doctrine that "naming could control the unknown" or that knowledge of the verbal sign permits one to manipulate reality. The sentiments underlying Andrei Bely's essay "The Magic of Words," with its invocation of a zvukovaia taina or a "secret to the very sound of things," were wholly foreign to Bakhtin. He steered clear of the theurgist, incantational, mystagogical or occult aspects of language, so in vogue during his youth. And of course, he had scant sympathy for the Symbolist and Futurist concept of time as millenarian, where empirical speech matters less than hieratic speech prophecy. In sum, for a Russian literary critic, Bakhtin was almost a pragmatic realist, remarkably phlegmatic about the ability of literary consciousness to transform the world. His logos-centrism, such as it was, differed profoundly from that of his contemporaries. He was ambitious for the word in another way.

Let us suspend those reservations about Bakhtin's reading of Dostoevsky, then, and consider one attempt to examine this "new cultural paradigm" at its root. In an essay published in the 1991 volume M. M. Bakhtin and Philosophical Culture of the Twentieth Century, Boris Egorov relates dialogism to the revolution in scientific thought preceding and following the Great War. ${ }^{30}$ During that decade, he reminds us, the positivism, linearity and "singularity" of nineteenth-century thinking across a wide number of fields (philosophy, political economy, biology and the natural sciences) gave way to new pluralist and multi-perspectival models inspired by Einsteinian thought (15). More strictly scientific fields made this transition with remarkable speed - and, Egorov notes, Bakhtin was determined that literary consciousness not fall

30 B. F. Egorov, "Dialogizm M. M. Bakhtina na fone nauchnoi mysli 1920-kh godov," in M. M. Bakhtin i filosofskaia kul'tura XX veka, ed. K. G. Isupov (St. Petersburg: Obrazovanie, 1991), 1:7-16. Further page references in text. 
behind. The young, intellectually precocious Bakhtin was passionate about a global coordination of paradigm shifts; a humanist, he poorly concealed his competition with the exact sciences.

Bakhtin's determination to connect the principles underlying modern physics with the principles animating human culture reflected the maximalist, unifying aspirations of Russian thought in general, to which Bakhtin was in no sense immune. Such ambitions are always alluring and always dangerous, Egorov remarks. For natural science is obliged to reckon neither with memory nor with faith - and in any event cannot afford to legitimate itself through such factors - whereas human culture (and especially culture as understood in the religious circles that Bakhtin frequented throughout the 1920s) cannot afford to ignore them. Such postulates as "universal relativity, dialogic ambivalence, the instability or transitoriness of all sensations and concepts," if moved mechanically from science into the humanities, could result in a destruction of "the very bases of human culture: the durability of traditions, ethical commandments and prohibitions, and other so-called 'eternal' categories" (15). Principles of relativity and ambivalence function differently among human beings than among particles of the universe. During a scientific revolution of such magnitude, only religious faith, with its a priori ideals and monologic dogma, "could offer a substantial counterweight to all the varieties of subjectivism and relativism" that would otherwise spin out of control. Bakhtin, a believer, presumed this counterweight to be in place. Religious consciousness would provide the proper discipline for dialogic relations occurring under the newly "relativized" conditions. But as Soviet history unfolded, cultural professionals in Bolshevik Russia (beginning with the atheistic formalists) were increasingly incapable of preserving, and soon even of perceiving, this anchor of Bakhtin's thought.

How might Egorov's remarks help us to modify the severe judgment on Bakhtin's polyphonic image of Dostoevsky? Linetsky and Ginzburg are wrong, I believe, when they suggest that Bakhtin does not appreciate ordinary dialogue, dialogue "in the traditional sense of the term." There is every indication that Bakhtin follows Dostoevsky in his reverence for such crystalline moments, which are awarded to innocent children, to beloved elders, and to the state of prayer. (Just such a dialogic moment descends upon Raskolnikov when, after Marmeladov's death, he asks Sonya's stepsister Polina to love him and pray for "thy servant Rodion.") If the hero of a novel functions not solely as a character acting out an uncomplicated plot function, however, but also as an idea-person [ideia- 
chelovek, a "person born of the idea"31] — that is, when a person is run by living concepts rather than by biology, a detective plot, or grace - then such ordinary, declamatory, preciously wonderful dialogues are extremely difficult to conduct. Such is the natural logic, or pressure, of polyphonic design. Sonya Marmeladova, almost wholly silent and rarely in control of her words, stands on the threshold between inner and outer acts. By contemplating her iconic image, Raskolnikov is driven forcibly over that threshold back into real-life communication (to confession and public trial) - not out of guilt, for he never acknowledges his guilt, but out of weariness and loneliness, as the only relief possible from the cacophony of unfinalized inner dialogue. Read Bakhtin carefully, and you will see that nowhere does he suggest that dialogue between real people necessarily brings truth, beauty, happiness or honesty. It brings only concretization (and even that is temporary), and the possibility of change, of some forward movement. Under optimal conditions, dialogue provides options. But there can still be mutual deception, mountains of lies exchanged, pressing desires unanswered or unregistered, gratuitous cruelty administered on terrain to which only the intimate beloved has access. By having a real other respond to me, I am spared one thing only: the worst cumulative effects of my own echo-chamber of words.

This being the case, one could argue that Kariakin, too, is only partially correct when he regrets the absence of a "finger pointing toward the truth" in Bakhtin's polyphony. For an ethical trajectory could be seen as inherent from the start in this spiraling alternation between polyphonic internalization of dialogue followed by escape from its unbearable torments. Moral growth might even be inevitable in novels of the sort Dostoevsky designed, where the chief crime is not murder, not even psychic cruelty, but the drive for excessive autonomy and the human failing that fuels this drive, which is spiritual pride. If (so this argument goes) I proudly internalize all dialogue so as "not to depend" on another's personality, or body, or service, or idea - I will never be at peace again. Inner dialogue will give me no rest. Not because

31 See PDP, Ch. 3, "The Idea in Dostoevsky": "It is not the idea in itself that is the "hero of Dostoevsky's works,' as Engelhardt has claimed, but rather the person born of that idea. It again must be emphasized that the hero in Dostoevsky is a person of the idea: this is not a character, not a temperament, not a social or psychological type; such externalized and finalized images of persons cannot of course be combined with the image of a fully valid idea. It would be absurd, for example, even to attempt to combine Raskolnikov's idea, which we understand and feel (according to Dostoevsky an idea can and must not only be understood, but also "felt") with his finalized character..." (85). 
I feel guilty, repentant, or even interested in another person's point of view (Raskolnikov was none of those things, even at the end) but because only external others, in responding to me, can check the monstrous growth of my own view on things, can concretize my thoughts long enough for me to get outside of them, assess them, and thus stand a chance to tame or modify them. Since no major Dostoevskian personality can survive a state of hyperactive inner dialogue for long, either suicide, or some form of religious conversion out of that solitary vortex, is unavoidable.

In sum: critics of dialogism and polyphony are correct that Bakhtin underestimates (as Dostoevsky never does) the sheer viciousness of the criminal imagination. True, Bakhtin was thoroughly familiar with bodily pain, not surprised by cruelty and not offended by death. He can also be faulted, it seems, for a lack of interest in the negative emotions and venial sins that, for many readers, constitute the core attraction of Dostoevsky's plots: lechery, lying, jealousy, greed, perversion and violence. To Mikhail Gasparov's complaint that Bakhtin too quickly encourages us to "expropriate others' words" and turn them to our own selfish use, Bakhtin would nod sadly in agreement: indeed, there is no reason why this process of appropriation need be virtuous, happy, healthy, or just — but it is universal. Although unimpressed by many of the stimulants natural to novels, about the inescapability of dialogue and the cost that dialogue exacts, Bakhtin is not naive.

Let us now sum up the fate of polyphony. Bakhtin was fascinated with scientistic models. He had come to maturity in an era entralled by numerical manipulation and classification: series, sets, groups, the emergence of sociology as a profession. Numbers lent themselves to grids and structures. And much like Wittgenstein at a slightly later time, Bakhtin was concerned to preserve the principle of relationalism without endorsing system-based structuralism (and why indeed should relationships, to be valid, organize themselves into a system?). Still, as the best Bakhtin scholars now acknowledge, a pure and unalloyed polyphony challenges not just systematic thought but also the very integrity of the personalities it pulls in. ${ }^{32}$ Bakhtin himself returned to the ambiguities of the method

32 Russian philosophers have thoroughly explored the shortcomings of the dialogic model and the danger of taking Bakhtin's ideal of polyphony too literally. As Liudmila Gogotishvili paraphrased the familiar complaint in her 1992 essay on the problem of Bakhtin's "evaluative relativism": "If speech belongs in turn first to me, then to the other, then to us, then to some third, and there is no superior possessor of meaning who might cap this uncoordinated clamor of voices with its own centralizing word, then 
a half-century after he had coined the concept, in this note: "The pecularities of polyphony. The lack of finalization of the polyphonic dialogue... These dialogues are conducted by unfinalized individual personalities and not by psychological subjects. The somewhat unembodied quality of these personalities (disinterested surplus)." 33 Disinterested, perhaps even "somewhat unembodied," the "unfinalized individual personalities" who engage in polyphonic dialogue constitute a wondrous population: secure, full of the virtues, free of humiliating dependencies. It is not easy to see ourselves in it. And from our outsiderly perspective, therefore, we must confirm that as a reader of literary and real-life scenes there are certain things Bakhtin cannot do.

First. As a rule, Bakhtin does not do beginnings and ends. He largely does middles. Wholly committed to process and to the dynamics of response, Bakhtin concerns himself much less with how something starts (a personality, a responsibility) or how it might be brought to an effective, well-shaped end. This neglect of genesis and overall indifference to closure left a profound trace on his thought, imparting to his literary readings their strange, aerated, often fragmentary character. The passion for the ongoing middle of a text also separates him profoundly from his subject Dostoevsky, perhaps

it follows that the meaning of speech in Bakhtin's scheme of things loses all its objective features. If there is no direct word, that is, no word issuing forth from a stable 'I' or 'we' and confidently addressed to its object, it means that linguistic form cannot have any truth-significance at all. As a matter of principle, such a word cannot contain in itself the truth of the world" (145). Gogotishvili then answers this complaint. The error here, she advises, is the old one of assuming that people are like things, that they can attach themselves to values with no work or risk, and that a truth need be singular or eternal. Acknowledging any sort of a "we" where one can rest - and such first-personplurals usually come to us in the form of genres - requires a great deal of individual effort (147). Gogotishvili notes four axes for registering meaning in an utterance - one's speech center, point of view, focus of attention, and the range of the self's participation in the world. Along all of them, in genres as small as an exclamation and as lengthy as a novel-absolute polyphony is impossible (152). Nor is it desirable. But polyphonic aspirations are not for that reason fraudulent, reductive, or self-serving. Polyphony is a generator. It generates boundaries, which are required to keep individual voices vulnerable and distinct from one another. For "the absence of a unified and singular direct word is not the absence of an idea or a rejection of higher values, but precisely the contrary: the fact that every speech manner is highlighted and conditioned by others is what protects the cultured word from barbarism" (172). L. Gogotishvili, "Filosofiia iazyka M. M. Bakhtina i problema tsennostnogo reliativizma," in M.M. Bakhtin kak filosof, eds.L. Gogotishvili and P. S. Gurevich (Moscow: Nauka, 1992), 142-74.

“From Notes Made in 1970-71," SpG 86, 151. 
the nineteenth century's greatest prose poet of original sin, Revelation, and Apocalypse. ${ }^{34}$

Second, Bakhtin cannot hear a fully self-confident monologue anywhere. As he matured, he became increasingly adamant on this point. In his view, even language deliberately employed "monologically" - in ultimatums, categorical farewells, suicide notes, military commands - in fact wants to be answered; it wants to be taken as only the penultimate word, and the person who utters such bits of monologic speech is always hoping that the person who hears it will care enough (against all odds and linguistic cues) to answer back. Within such heightened fields of expectation, a failure to respond is itself a response, giving rise to its own fully-voiced anguish. As long as we are alive, we have no right to pull out on another person who addresses us in need - and no right, apparently, to be left alone. No single moment is ever wholly authoritative or closed for Bakhtin. Even dying, it turns out, is no guarantee of an escape from dialogue.

Third, somewhat like Dostoevsky's Idiot Prince Myshkin - and very unlike Dostoevsky himself-Bakhtin was temperamentally unfit for polemics. He would not condemn or exclude. All memoir accounts of Bakhtin emphasize this aspect of his mature personality: whether due to tolerance, languor, aristocratic disdain, commitment to dialogue, carnival optimism, Christian meekness, or simply fatigue, chronic illness and pain - there was, as one Jubilee memoirist put it, a sort of "lightness," legkost', to Bakhtin's person that made it absolutely impossible for him to take a firm or final stand on a question, to impose rigid constraints, or to endorse any form of violence. ${ }^{35}$ This "lightness" has proved a serious obstacle to politicizing his thought. It also shaped his understanding of polyphony in Dostoevsky.

34 Without a doubt, beginnings and ends fascinated the novelist. To be fascinated does not mean to understand their causes, however. See, for example, these lines from Dostoevsky's essay "Two Suicides": "We know only the daily flow of the things we see, and this only on the surface; but the ends and the beginnings are things that, for human beings, still lie in the realm of the fantastic." October 1976 entry in Fyodor Dostoevsky, A Writer's Diary, trans. Kenneth Lantz (Evanston: Northwestern University Press, 1993), 1:651. Although Bakhtin remarked on several occasions that faith in a "miracle" [chudo] was both necessary and proper in life, he was far less willing than Dostoevsky to theorize about "fantastical" or mystical material.

35 Sergei Averintsev, "V stikhii 'bol'shogo vremeni," Literaturnaia gazeta 15, no. 45 (November 1995): 6. 


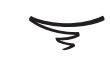

This excerpt on carnival from Chapter 4 of The First Hundred Years of Mikhail Bakhtin (Princeton University Press, 1997) also reflects an awareness - and wariness of the Bakhtin boom, which was launched in the West during the late 1960s around this malleable, inflammable, and poorly-translated concept. It interpolates several pages from Chapter 2 describing Bakhtin's dissertation defense. The whole of this section is briefer than the polyphony discussion, since my appreciation of the carnival principle (which remains for me a confusion and a challenge) was updated five years later; that essay from 2002 is excerpted later in this section.

Opening and closing segments from chapter 4 (plus a section from chapter 2) of The First Hundred Years of Mikhail Bakhtin:

\section{CARNIVAL: OPEN-ENDED BODIES AND ANACHRONISTIC HISTORIES (1997)}

"M. Bakhtin possessed a genuinely philosophical gift for broadening out problems." 36 With this sentence, E. Yu. Savinova opens her 1991 essay entitled "Carnivalization and the Wholeness of Culture" - and as evidence of this breadth, she brings forward the fact that Bakhtin's "research into the writings of Rabelais resulted in the discovery of a completely new layer of culture in the Middle Ages and the Renaissance, which, in turn, altered the entire picture of the development of human culture." Savinova overstates the case, but in spirit she is correct. Of all Bakhtin's ideas, "the problem of carnival" has proved the broadest, most appealing, most accessible, and most readily translatable into cultures and times distant from its original inspiration.

E. Yu. Savinova, “Karnavalizatsiia i tselostnost' kul'tury," in M. M. Bakhtin i filosofskaia kul'tura XX veka, ed. K. G. Isupov (St. Petersburg: Obrazovanie, 1991), 1:61-66, esp. 61. 
This ready translatability has been both a handicap and a boon. The handicaps are those that a skeptic detects in Bakhtinian dialogue as well: a somewhat facile solution to human aloneness; an indifference to compulsion and violence; naïve utopianism (in this case of the body rather than the word); a certain sentimentalism; a dismissal of history. But the boons brought to scholarship by the idea of Bakhtinian carnival have also been very real. Three years after the Rabelais book was published, an enthusiastic review article by a Soviet Sinologist appeared in the professional journal Narody Azii i Afriki [Peoples of Asia and Africa] titled, simply, "Reading Bakhtin." 37 The body of the article is devoted to the role played in Chinese culture by holidays, festive processions, and folk wisdom in anecdotes about Confucius. Its author credits Bakhtin with providing her with the scholarly precedent. Such irreverent celebratory rituals are under-researched in a field like Sinology, she notes, which has been dominated for so long by the study of the region's powerful, serious, duty-laden religions. Reading Bakhtin's book on a French writer opened up rich possibilities for her study of China; in fact, "the 'popular laughing carnival culture' that Bakhtin discovered makes available a new, fruitful elaboration of the two-cultures problem in every national culture" (106). Like Freud's fantasy of a single family romance that unfolds in each human psyche without exception, Bakhtin's carnival idea has the thrill of a cultural and biological universal.

As a communication model, carnival dynamics has much to recommend it. The suspension of everyday anxieties during "holiday time" and "carnival space" - the specific locus being the grotesque body, vulnerable yet superbly shame-free - rids both me and my most proximate neighbor of the excessive self-consciousness that keeps each of us lonely, our words insipid, our spontaneous gestures of outreach in check. (Remarkably, Bakhtin - a chain smoker and tea addict - attends almost not at all to the chemical side of carnival, that is, to intoxication, addiction, or drunkenness, although any practical understanding of holiday bawdiness or vulgarity is unthinkable without it. ${ }^{38}$ ) For the carnival self is not a wholly conscious entity. Its ideal page references in text.

38 The issue has received sensible attention in the West; see Marty Roth, "Carnival, Creativity, and the Sublimation of Drunkenness," Mosaic 30, no. 2 (June 1997): 1-18. Exploring the ancient linkage of intoxication with creativity and its reflection in "the Dionysian esthetic of Nietzsche and the carnival esthetics of Bakhtin," Roth notes that although carnival is unthinkable without drink and drugs, "mood-altering substances are left out of the mix that produces the Bakhtinian carnival, with the result that 
is the open-ended and irregular body, which has no need for visions of symmetrical beauty, feats of self-discipline, or personalized acts of genuine intimacy. If the products of the mind (words, verbal dialogue, polyphonic maneuvers) are fastidiously individualizing and take a great deal of work to get right, then an imperfect body, by contrast, is something each of us possesses by definition - indeed, almost by default. However we might age, we will, in the natural order of things, have more of such a body, not less. To affirm it, therefore, requires no special effort; in fact, to affirm it is an enormous relief.

It follows that entry into the world and worldview of carnival costs ridiculously little. Even without any special accent on the grotesque, we would all probably agree that much of our basic physiology-located in what Bakhtin calls the "lower bodily stratum" — is identical, involuntary, and non-negotiable. Its processes and appetites can thus be said to constitute (in a metaphor popular with postmodern critics) a common "language," native to all humans. And yet, as Bakhtin describes it in his book on Rabelais, the common language of bodies is of a certain highly convenient sort. Whereas verbal languages must be learned, internalized, teased out of the mind - and even then, they can be easily "misspoken" at the level of form as well as intent - the body (and even more, the grotesque body) cannot misstep or make a mistake. It is by definition already out of step; and in any case a faux pas would not be noticed or remembered. The carnival body is available to all without discrimination. ${ }^{39}$ Its energy and material structures are displayed, as

Bakhtin and his commentators cannot offer any explanation for that festive institution beyond itself" (1). Bakhtin might answer that one such explanation was famine. On the mystique of a good cigarette for Bakhtin, see Galina Ponomareva's remark that the first question Bakhtin asked her during their initial meeting was whether or not she smoked; answering in the negative, she relates, "at that moment I discovered how important it was for him - I wouldn't want to say it was a sacred ritual, but still — this communion while smoking, even if at times a wordless communion." Visitors could easily "sniff their way" to the Bakhtins' smoke-saturated apartment in Saransk and Moscow. G. B. Ponomareva, "Vyskazannoe i nevyskazannoe... (Vospominaniia o M. M. Bakhtine)," Dialog. Karnaval. Khronotop 3 (1995): 59-77, esp. 61. [Henceforth DKKh.] See also the (by now apocryphal) comment made by Bakhtin to one of his undergraduate advisees in Saransk, who "always saw him sitting at his desk... and uninterruptedly smoking: as soon as one cigarette was finished he immediately lit up another. A cup of strong tea. 'For some it is harmful to smoke,' [Bakhtin] often remarked; 'for others it is necessary to smoke." Yu. D. Ryskin, “Moi vospominaniia o M. M. Bakhtine," in M. M. Bakhtin v zerkalo kritiki, ed. T. G. Yurchenko (Moscow: Labirint, 1995), 111-13, esp. 112.

39 See Mikhail Bakhtin, Rabelais and His World, trans. Hélène Iswolsky (Bloomington: Indiana University Press, 1984), esp. ch. 5, "The Grotesque Image of the Body." One unfortunate mistranslation in this uninspired but serviceable English version is the 
it were, on an exoskeleton, turned toward the outside world in a frank and welcoming way. Such communal "baseness," the vigor of le bas corporel, is the foundation of Bakhtin's carnival logic. It can be fueled by denunciation and aggressive rhetoric but is apparently tainted by neither; its laughter, even when defiant, is rejuvenating. Since the grotesque body costs nothing to keep up, does not care if it wears out, has neither vanity nor fear of pain, cannot be self-sufficient, and is always "a body in the act of becoming," it is guaranteed to triumph over classical form, institutional oppression, and individual death.

The optimism of all this is dazzling. The spirit of carnival grows out of Bakhtin's larger concept of smekhovaia kul'tura, a "culture of laughter," and the idea has proved irresistible. Although sensed as potentially subversive, unlike so many subversions elaborated by intellectuals it is not elitist (for we are working here-literally - with the lowest common human denominators). It promises a sort of freedom, even though the structures that grant this freedom are perceived as fixed and monolithic. Carnival and its corollary values moved with astonishing speed to inspire Paris 1968, British postcolonial theory, Latin American literature, continental and American feminist thought. The Rabelais book became a bestseller. On Russian soil, however, Bakhtin's carnival idea had a difficult and suspicious reception from the start, indeed, from the very day of Bakhtin's protracted and controversial dissertation defense.

Bakhtin's formal education had been interrupted by the chaos of civil war and by poor health; since childhood he had suffered from chronic osteomyelitis. After 1938, following the amputation of his right leg, Bakhtin's health improved. Two years later, in 1940, hoping to increase his qualifications for steady employment by possession of an advanced degree, Bakhtin submitted his study "Rabelais in the History of Realism" to the Gorky Institute of World Literature as a dissertation (although he never liked to refer to his book as such). The War intervened; he defended formally only in 1946, on the brink of a new wave of High-Stalinist xenophobia. Notwithstanding a divided vote slightly in his favor, he was eventually certified - in 1951, after a fiveyear delay - with the lesser academic degree of kandidat rather than doktor nauk. Before the dissertation could be approved and filed in public libraries,

rendering of chrevo, (Russian for the "belly/womb" or generalized region of digestive and generative functions, not of excrement per se), as "bowels": cf. p. 317, where the grotesque body, forever outgrowing and transgressing itself, allots an essential role to "those parts ... in which it conceives a new second body: chrevo i fall [the belly/womb and phallus]" (not, as Iswolsky has it, "the bowels and the phallus"). 
however, Bakhtin was required to cleanse and reorient those portions of the text that made his work, in the opinion of the Higher Accrediting Commission, "crudely physiological," bawdy, and "ideologically depraved." 40 The book that was published in Russian in 1965 and subsequently translated into the languages of the world was based on this shortened, sanitized version of the dissertation. The full stenographic transcription of Bakhtin's 1946 defense was published only in $1993 .{ }^{41}$

This transcript of the Ph.D. defense provides a fascinating glimpse into the dynamics of Stalin-era academic life. In a procedure that was far from routine for those years, independently-minded colleagues within the university took a bold stand in defense of their wayward candidate. Almost all the major arguments pro and contra carnival, the grotesque body, and cultures of laughter that we meet in the 1960s and 1970s were first broached during Bakhtin's dissertation defense twenty years earlier — in which context Bakhtin himself had a chance (indeed, an obligation) to respond and defend his hypotheses. This is precious information, because the septuagenarian Bakhtin of the 1960s and 70s rarely bothered to rebut criticism (or to court praise) when his works finally began to appear in print. He considered himself either above, or to the side of, such dialogue. Thus his required response, at age fifty, to his opponenty (the formal examiners at his defense) is one of the few sustained self-reflections we have by Bakhtin on his own work. What major objections were raised to Rabelais in the History of Realism in 1946, and how did Bakhtin justify his work in light of them?

40 The phrase here is "ideologicheski porochnoi" (guilty of an ideological sin). See the memoir by Bakhtin's enthusiastic supporter E. M. Evnina, who, as a junior scholar during these years, was required to "remove from the manuscript of her own book on Rabelais all citations and references to Mikhail Mikhailovich's dissertation." The Higher Accrediting Commission (VAK) criticized Bakhtin's scholarly work as "Freudian," "pseudoscientific," "formalistic," and, to the extent that the original submission contained a chapter on this great Russian writer, disrespectful to the genius of Gogol. See "Iz vospominanii E. M. Evninoi," appendix 3, DKKh 2-3 (1993): 114-17, esp. 117.

41 See "Stenogramma zasedaniia uchenogo soveta instituta mirovoi literatury im. A. M. Gor'kogo: zashchita dissertatsii tov. Bakhtinym na temu 'Rable v istorii realizma' 15 noiabria 1946 g.," annotated by N. A. Pan'kov, DKKh 2-3 (1993): 55-119. In addition, the issue includes a lengthy background essay by Pan'kov (29-54) as well as four appendices: the text of Bakhtin's formal dissertation prospectus or "tesizy;" a conversation with the literary scholar Valery Kirpotkin; a memoir on the fate of Bakhtin's dissertation after the defense by a fellow Rabelais scholar, E. M. Evnina, who was banned from citing it; and a brief statement (1944) in favor of Bakhtin's monograph by the eminent Formalist critic Boris Tomashevsky. 
In many respects, Bakhtin's thesis was ingeniously appropriate for its time and place. Many clichés of communism are realized in it: carnival, after all, could easily be linked with the "common people," the collective body, and a buoyant disregard for individual death. Carnival had the additional advantage of being pro-materialist, anti-Church, disruptive of fixed order, and vaguely "revolutionary," both on its own terms and vis-à-vis more humanistic Western readings of Rabelais. Although prim, oppressive Stalinist culture had long since ceased to live by those destabilizing Bolshevik slogans, as verbal tags they could still embarrass and deflect hostile attacks. One Comrade Teriaeva, an examiner of few scholarly qualifications but with rigid Stalinist convictions and a good nose for treason, ${ }^{42}$ accused Bakhtin of failing to reflect in his dissertation (submitted in 1940) the spirit of Zhdanov's 1946 proclamation on party-mindedness in literature. She also condemned his work for resembling more "private research" full of "superfluous references to Saturnalia and phallic cults" than an objective study of class antagonisms. Bakhtin responded in his final statement - with what must have been profound weariness - that his study dealt with one of the world's most revolutionary writers, that he saw no reason to write "what had already been written and spoken," that Comrade Teriaeva apparently wanted him simply to repeat "what she had already studied," and that "I, as a scholar, can be a revolutionary as well... I solved the problem [of Rabelais] in a revolutionary way." 43

There were also responsible objections raised at the defense, however, by those who appreciated fully the value and originality of Bakhtin's work. Where is the spiritually serious side of humanism? Why is the great realist François Rabelais (whose role as author, artist, and cleric is scarcely discussed) cast backward into the Middle Ages and not forward, progressively, into the Renaissance? On what basis can the dissertator claim that mediaeval carnival or carnival laughter is so carefree and eternally "cheerful"? Why such simplistic binary thinking, which presumes that grotesque realism is solely the property of the masses - when in fact all strata of society

For a brief and exasperated professional biography of Mariia Prokofievna Teriaeva, see N. A. Pan'kov, “'Ot khoda etogo dela zavisit vse dal'neishee ...' (Zashchita dissertatsii M. M. Bakhtina kak real'noe sobytie, vysokaia drama i nauchnaia komediia)," in DKKh 2-3 (1993): 29-54, esp. 47-48. To this "Iago in skirts," literary toady and spy, specialist on "Stendhal and bourgeois realism" and thoroughly Stalinist persona, Pan'kov would "like to devote an entire sarcastic-annihilating diatribe."

43 Bakhtin's summary statement [zakliuchitel'noe slovo], "Stenogramma zasedaniia..," 98-99. Further pages references given in text. 
(even those Bakhtin excoriates as "official") can be shown to have indulged delightedly in it? And for that matter, why do the commoners in Bakhtin's account only laugh and cavort, when in history they clearly broke their backs with work, suffered, and thirsted to believe? The entire hypothesis of "reduced carnivalization" in subsequent literary epochs struck some examiners as an artificial construct. Can one really leap unproblematically from Rabelaisian folkloric fantasy to Gogol's ambivalent humor or to Dostoevsky's tragic vision?

In his final statement, Bakhtin addressed these reservations, although in no sense apologetically. His kindly, aristocratic demeanor - tolerant of others because indifferent to their opinions - glimmers beneath the transcript. "I am an obsessed innovator," he admitted. "Obsessed innovators are very rarely understood." He was deeply gratified, therefore, for the support he had received and grateful for a chance to respond to objections. Yes, in his thesis (far too short for the task he had in mind) perhaps he had exaggerated and simplified cultural traditions as well as historical conditions. "I did not present Rabelais in the atmosphere of the French Renaissance. This is true. I did not do so, because in that area so much has already been done, and I would have addressed you here as a mere compiler. And why is that necessary, when those materials are available to everyone?... To repeat [what is known] is to beat down an open door" (94). In any future monograph, he assured his examiners, he would balance the record with attention to Rabelais the humanist. But as he had testified in his opening statement, the gothic and the grotesque had fared so poorly in literary scholarship - methodologically always partial to forms of "prepared and completed existence" - that in his study he had resolved to "catch existence in the process of becoming" (56) and to consider the epoch solely from that "unofficial," as yet uncoalesced point of view. As regards laughter, Bakhtin hastened to assure his audience: "I do not in the least mean to imply that mediaeval laughter is cheerful, carefree and joyous laughter" (97). In carnival, laughter and death are intertwined; death and pain are everywhere and are grimly real, only death never has the final word. "Laughter is a weapon, like fists and sticks." But unlike those latter two weapons, which can be wielded effectively in anger and in dread, laughter must be absolutely fearless; for precisely this reason it is progressive, pointed forward toward the Renaissance. "Laughter liberates us from fear, and this work of laughter... is an indispensable prerequisite for Renaissance consciousness. In order to look at the world soberly, I must cease to be afraid. In this, laughter played a most serious role"(98). No, Rabelaisian realism is not degraded, dirty, or an insult to consciousness; it is a forerunner 
of all objective critical consciousness. Of course the common people do not only laugh; they have many lives. "But this is the life that interested me, it is deeply progressive and revolutionary.... Excuse me if I have not satisfied you with my answers, I am so exhausted, and it shows" (100).

Despite these assurances at the defense, Bakhtin did not alter the text of his dissertation in a "more balanced," humanistic direction before seeking a publisher. In fact, his first attempt to publish was in 1940, soon after he submitted the text to the Gorky Institute. In 1944 he tried a second time to publish the text, also unsuccessfully, although there survives from that period a long set of notes, published for the first time in 1992 under the title "Additions and Revisions to Rabelais," indicating the scope of Bakhtin's ambitions for the larger project. ${ }^{44}$ Projected chapters were to deal with official (that is, bad) versus unofficial (good) seriousness; with carnival as a universal theory of "limbic" images; with carnivalized aspects of Hamlet, King Lear, Macbeth and presumably other Shakespearean drama; and there is some loose speculation on the relation of carnival to nicknames and gesture. Regretfully, little of this plan was realized. The sanitized version required by the dissertation committee became the canonical text (apparently Bakhtin's 1940 Ur-Rabelais has disappeared)..$^{45}$ For twenty-five years these quasi-public presentations, resubmissions, rumors of reader reports and memoirs from the audience entered public memory. Apocryphal and carnivalized stories began to circulate, such as the (unconfirmed) account by one eyewitness at the doctoral defense that "at the culminating moment, Bakhtin shouted at his opponents: 'Obscurantists! Obscurantists!' - and furiously banged his crutches on the floor." 46 In a word, by the time the typescript finally saw the light of day, it had accumulated an entire shadow history of legends.

As we know from Bakhtin's personal correspondence with Leonid Pinsky, Shakespeare scholar and fellow political exile, as late as 1960 Bakhtin considered his work on Rabelais and the history of laughter, however "cleansed," still unpublishable. ${ }^{47}$ By the early 1960s, however,

44 M. M. Bakhtin, "Dopolneniia i izmeneniia k 'Rable”" [dated 18/VI/44], prepared for publication by L. S. Melikhova, first published in Voprosy filosofii 1 (1992): 134-64.

45 Pan'kov, “'Ot khoda etogo dela...," in DKKh 2-3 (1993): 40.

46 The eyewitness was B. I. Purishchev; the anecdote was related to Pan'kov by Iu. M. Kagan, Matvei Kagan's daughter. See Pan'kov, “'Ot knoda etogo dela...”" 42.

47 See Bakhtin's letter to Pinsky, 26 November 1960: “As regards my work on Rabelais, I am not counting on any possibility of its publication. What is more, it was finished twenty years ago and a great deal no longer satisfies me." "Pis'ma M. M. Bakhtina $\mathrm{k}$ L. E. Pinskomu," ed. N. A. Pan'kov, in DKKh 2 (1994): 57. 
conditions had changed. After perilous delays, the Dostoevsky book had appeared in a revised edition. But Dostoevsky, for all his ideological unruliness, was nevertheless Russian and canonical; Rabelais was Western and (in Bakhtin's reading) indecent. Carnival laughter on the public square might be indeed "revolutionary" and "of the masses" - points stressed repeatedly by Bakhtin during his dissertation defense - but it was also a good deal more dangerous and potentially anarchic than the dialogic word in the novel, a genre designed for solitary individual consumption. It remains the most disputed image in the Bakhtin canon.

By the early 1990s, the problems with Bakhtin's carnival concept had been thoroughly aired by detractors and enthusiasts alike. No one doubted that Bakhtin's image was a utopian construct. Cultural historians from both East and West had persistently pointed out that real-life carnival rituals - while perhaps great drunken fun for the short term - were not necessarily cheerful or carefree. In its function as society's safety valve, a scheduled event that domesticated conflict by temporarily sanctioning victimization, medieval carnival in practice was frequently more repressive than liberating. Bakhtin's reluctance to highlight the crucial role of violence and scapegoating during carnival baffled many of his readers. And then there was the stiff binary nature of Bakhtin's social history, which presents such a strange image of popular appetites and upper-class taste. Since Bakhtin analyzes Rabelais's novel not primarily as an authored piece of literature but through the lens of preliterate (and arguably multinational) folklore, he tends to dehistoricize the text; in its pages, French medieval society appears rigidly and artificially stratified. Bakhtin functions more as a mythographer than as a literary scholar or social historian. Perhaps mythography even suited Bakhtin's intent. By supplementing his schematicized, quasi-historical picture of Rabelais's France with timeless folk images, Bakhtin could provide his immediate Soviet audience with thinly disguised psychological universals that were relevant to any (and most persuasively, to his own) time.

These reservations about Bakhtin's Rabelais were summed up from a Russian perspective by Aleksandr Pan'kov in his centennial study The Key and Clue to M. Bakhtin. ${ }^{48}$ According to Pan'kov, Bakhtin's most repudiated value - traces of which could be found at the negative pole of every Bakhtinian binary - was ofitsioz, "officialese or official culture," the world as it looks when approved and controlled from a single sociopolitical center. 
Inside that center was stasis and silence, a moral void; the further one was from the center, the more talk, activity, variety and interest. Repelled from his earliest years by ofitsioz wherever it was found, Bakhtin "strove to extract from medieval ideology itself the principle of cultural two-worldness [dvoemirie]; he subjected living material to a typological cleansing ... and at times the material clearly resisted" (168). Bakhtin's "body of the people" lost all historical or literary reality, becoming directly mythological and populist (but in the nineteenth-century Russian, rather than medieval French, sense of that word). The folk or narod was invested with a Romantic "metaphysical vital value"; and although presented as wholly spontaneous, self-absorbed, unself-reflecting, this folk also functioned for Bakhtin, in Hegelian fashion, as a progressive mechanism that could move history (171). With this romanticized "people" fixed in place, official culture could be reinterpreted negatively as an "artificial construction, genetically 'alien," an imposition and a burden. Bakhtin's social history unfolded in a quasi-fictional realm that "at times began to recall the Wall between 'city' and 'nature' in Zamyatin's [dystopian] novel We" (171-72).

In closing, we might turn to a thoughtful centennial essay by I. N. Fridman, "Carnival in Isolation." 49 Fridman attaches carnival in a complex weave to its apparent opposite, polyphony - and more generally, to the "I-thou" relation that Bakhtin celebrates in his dialogism. But he imparts a darker cast to the whole, tying it more tightly to the pressures of Soviet ideology. He interprets both polyphony and carnival in light of the major realignments in Bakhtin's thought at the end of the 1920s. The dynamics of polyphony, he suggests, reflect Bakhtin's waning ideal hopes for what openness alone could do to keep creativity and consciousness alive. The quality of "completion" [zavershenie] - previously valued as full of grace, lovingly bestowed, pragmatically necessary in order that personality function properly and that a work of art emerge in our disorderly world - is reinterpreted as "closure" or "enclosedness" [zamknutost']. It becomes a destructive force that

I. N. Fridman, “Karnaval v odinochku," Voprosy filosofii 12 (1994): 79-98. Further page references in text. A similar thesis is suggested in Gary Saul Morson and Caryl Emerson, Mikhail Bakhtin: Creation of a Prosaics (Stanford: Stanford University Press, 1990), Part One, chapter 2. 
behaves like "a robber on the high road," stealing up on us and attacking from behind (85). This shift from benignly beneficial to criminalized closure strikes Fridman as fatal, not just for Bakhtinian aesthetics but for any aesthetics; for in his view, once the aesthetic pleasure of catharsis has been exiled from the work of art, the boundary between life's processes and art's products cannot be sustained. According to Bakhtin's new understanding, ideas and forms (along with their human carriers) do not naturally desire consummation or resolution. Thus heroes, readers and authors are never taken down off the rack. The instability and psychic distress that accumulates in such a model eventually triggers the move from polyphony to carnival. For if the polyphonic image is "a 'world symposium' headed by an insane Chairman whose sole concern is that dialogue never end" (86) - Fridman's unkind paraphrase - then the only way Bakhtin can avoid this travestied extreme is to wrap the whole dialogic process in an anaesthetizing utopian envelope. Within that envelope, the "second life" of the mind in dialogue is like the laughing holiday, deeply authentic, perhaps, but suspended in both space and time.

According to Fridman, Bakhtinian polyphony and Bakhtinian carnival are equally utopian constructs. If Bakhtin's Dostoevsky book creates out of that author's world a personalist utopia of speaking minds, then the Rabelais book is its mirror opposite, a collective or rodovoe [clan-based] utopia of communing bodies (86). The two are connected, Fridman suggests, in the huge, new fourth chapter on genre in Problems of Dostoevsky's Poetics, added to the 1963 revision of the 1929 original book, through Bakhtin's eccentric concept of "genre memory" (87). This "memory of the genre" is really a sort of "ancestral or fore-memory" [pra-pamiat'], which combines elements of a collective preconscious with prerogatives of the conscious individual. Its one determining characteristic is that it seems to remember only what everyone else forgets. Bakhtin avoids the acknowledged classics in the art of the novel "like a danger zone"; and when he invokes genuine carnival forms, he lets it be known that any attempt to incorporate them into literature must reduce and distort them almost beyond recognition. For this reason, Fridman is reluctant to call Bakhtin an aesthetician at all. "The subject of Bakhtin's aesthetic theory," he writes, "its authentic substrate, are the peripheral zones lying on the threshold, on the border that divides art from pre- or supra-art, anything but art itself... [both the dialogic novel and the model of carnival] provide a definition of art - but only in the specific Bakhtinian sense of 'delineating the limits' of something, and even so, not from within but from 'without" (88). 
Fridman's comments lead us to the edge of that most fraught area in which Bakhtin has been rethought: vnenakhodimost', exotopy or "outsideness." The term refers both to the cardinal value Bakhtin placed on external perspective, as well as to Bakhtin's own multiple identity as literary scholar, culturologist and ethical philosopher, an outsider to all established disciplines and native to none. With their competing methodologies and different validating logics, are these various professions eroded when combined in his person? And if so, is this a blessing or a misfortune? For however we might sympathize with Bakhtin's antipathy toward "official thinking" [ofitsial'shchina, ofitsioz], there is much to recommend professionalism. An internal consistency of argument, an obligation to assess what others have seen and registered, a consensus over basic terms, an agreement as to what constitutes a misuse of evidence, the modest placement of oneself within an established language: in the best of worlds, these are virtues that professional insidership can foster. And even in the worst of worlds, which arguably was the Soviet Union circa 1930-1950, the cohesiveness of intellectual tradition and a sense of shared texts was what had kept Russian philological scholarship alive.

Bakhtin, however, did not seek to be an insider to things. In places he rivals Leo Tolstoy in his reluctance to join, endorse or build upon (with any degree of appreciation) a definition that precedes his own. And in matters of art, as it was for Tolstoy so it was, to some extent, for Bakhtin: art is not primarily a matter of pleasure, beauty, perfect proportion or disinterested play but the site of other, more essential tasks: self-identity, communicative exchange, moral growth. Beauty and aesthetic pleasure might even be said to get in the way. But then we might ask: does form in itself possess adequate resources to survive the pressures that Bakhtin applies to it? The role that form plays in other paradigms of the creative process is occupied in Bakhtin's scheme by an assortment of more vulnerable and porous matter: chronotopes, speech genres, voice zones, loopholes, participatory outsideness, aesthetic love. Can Bakhtin's mature aesthetic, derived from Kant, from the theory of relativity, from biofeedback models and the example of Christ, steeped in Goethe and Schelling, ever achieve the minimum disinterestedness, attention to details and to wholes, and respect for stable form that we have come to expect from a theory of art? 